\title{
Secondary metabolites production through biotechnological intervention: A Review
}

\author{
Sekh Abdul Nasim ${ }^{1}$, Junaid Aslam ${ }^{1,2 *}$, Rashmi Kapoor ${ }^{1}$, Saeed Ahmad Khan ${ }^{3}$ \\ ${ }^{1}$ Department of Botany, Faculty of Science, Hamdard University, New Delhi-110062, India; \\ ${ }^{2}$ Plant Tissue Culture Laboratory, Dubai Pharmacy College, Al-Muhaisanah 1, Al Mizhar, \\ P.O. Box 19099, Dubai, United Arab Emirates; ${ }^{3}$ Department of Pharmaceutical and \\ Medicinal Chemistry, Dubai Pharmacy College, Al-Muhaisanah 1, Al Mizhar, P.O. Box \\ 19099, Dubai, United Arab Emirates
}

\begin{abstract}
The plants used in the phyto-pharmaceutical preparations are obtained mainly from the natural growing areas. With the increasing demand for the crude drugs, the plants are being overexploited, threatening the survival of many rare species. In addition, agriculture land decreasing day by day due to the real estate, industrialization, and roads for the betterment of human beings. To maintain the required demand of the important secondary metabolites and their sources; several research institutions and pharmaceutical industries using advanced biotechnological tools, this includes culturing of plant cells, genetic manipulation aiming to restore the germplasm, insertion of interest of genes for the production of important active principle. The present review article covering the in vitro micropropagation and production of selected secondary metabolites through biotechnological intervention viz. Alliin, Artimisnin, Podophyllotoxin, and Taxol.
\end{abstract}

Keywords: Plant Tissue Culture, secondary metabolites, alliin, artimisnin, podophyllotoxin, taxol.

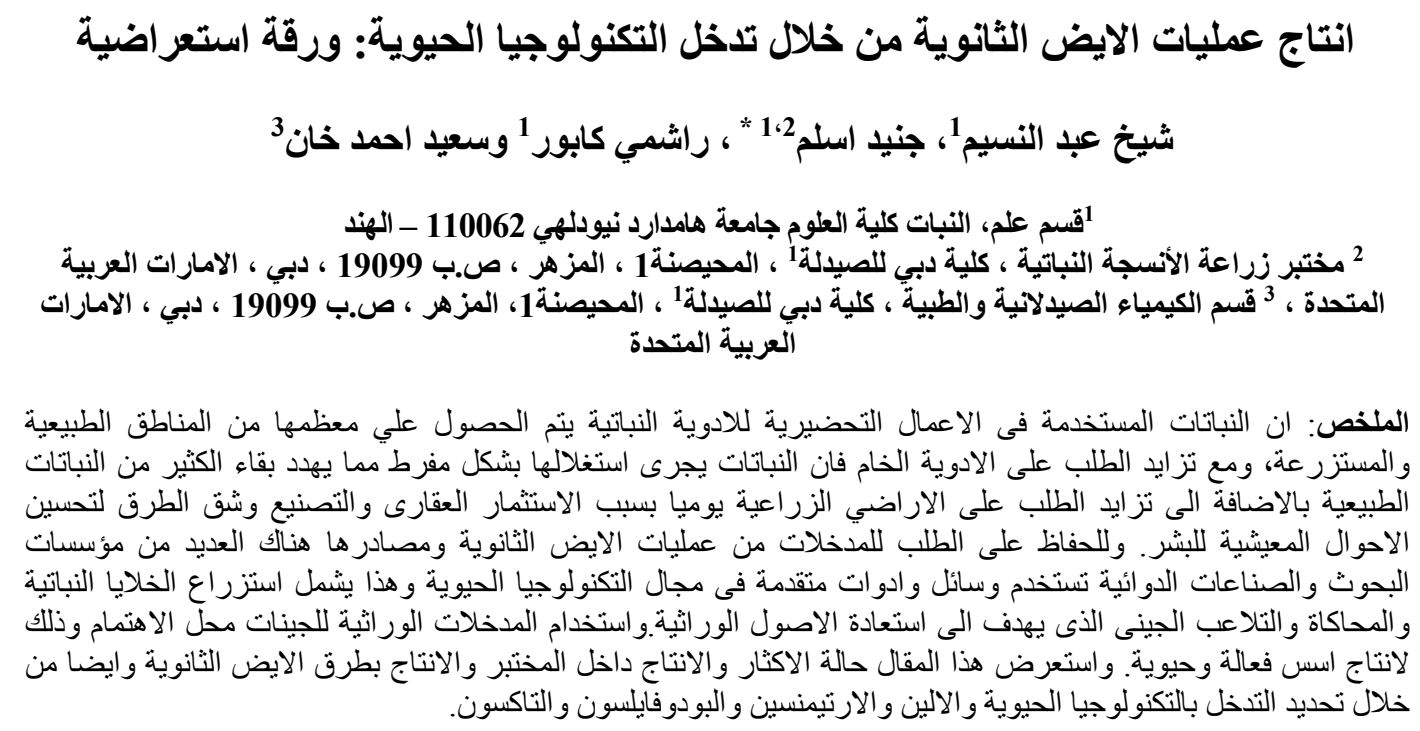

*Corresponding Author, Email: Junaidg1@gmail.com 


\section{Introduction}

In modern medicine, plants are used as sources of direct therapeutic agents, as models for new synthetic compounds, and as a taxonomic marker for discovery of new compounds. They serve as a raw material base for the elaboration of more complex semisynthetic chemical compounds (Akerele, 1992; Anonymous, 2001). The synthesis of bioactive compounds chemically is difficult because of their complex structure and high cost (Anonymous, 2001). Wide variations in medicinal quality and content in phytopharmaceutical preparations have been observed. They are influenced mainly by cultivation period, season of collection (Abdin et al., 2003). Generally, herbal preparations are produced from fieldgrown plants (Murch et al., 2000). It was difficult to ensure the quality control as the medicinal preparations are multi-herb preparations and it is difficult to identify and quantify the active constituents. An efficient and most suited alternative solution to the problems faced by the phytopharmaceutical industry is the development of in vitro systems for the production of medicinal plants and their extracts.

Plant tissue culture proved an important technology being used for the conservation of important plants either through organogenesis, somatic embryogenesis and genetic transformation (Sajc et al., 2000; Mujib and Samaj, 2006). The major advantages of cell cultures includes (i) synthesis of bioactive secondary metabolites independently from climatic and soil conditions; (ii) negative biological influences that affect secondary metabolites production in the nature are eliminated (microorganisms and insects) (iii) to select cultivars with higher production of secondary metabolites; (iv) with automatization of cell growth control and metabolic processes regulation, cost price can decrease and production increase (Jha et al., 1998; Abdin et al. 2003; Junaid et al., 2009; Junaid et al., 2010). The objectives of many industries are to develop plant cell culture techniques to the stage where they yield secondary products, more cheaply than extracting either the whole plant grown under natural conditions or synthesizing the product. Although the production of pharmaceuticals using plant cell cultures have been highlighted, other applications have also been suggested as a new route for the synthesis, products from plants difficult to grow, or in short supply, as a source of novel chemicals and as biotransformation systems. It is expected that the use, production of market price and structure would bring some of the other compounds to a commercial scale more rapidly and in vitro culture products may see further commercialization. (Doran, 2000; Ramachandra Rao and Ravishankar, 2002; Junaid et al., 2009, Nasim et al., 2009a).

\section{Production and accumulation of selected secondary metabolites from cell cultures} Plant cell culture holds much promise as a method for producing complex secondary metabolites in vitro (Ravishankar and Venkataraman, 1993; Junaid et al., 2009; Nasim et al., 2010; Junaid et al., 2010). The sources, medicinal significant and in vitro production have been reviewed here in, Alliin, Artemisinin, Podophyllotoxin and Taxol secondary metabolites.

\section{Alliin \\ Sources}

Garlic (Allium sativum) is the main sources of Alliin (Figure 1). It is a member of the lily family. It may be divided into two subspecies: Allium ophioscorodon (bolting or hard-neck cultivars) and Allium sativum (non-bolting or soft-neck cultivars). Allium ophioscorodon produces elongated flower stalks, often referred to as scapes, and flower-like bulbils at the top of the stalk. Soft-neck garlic does not produce bulbils except in times of stress. While 
both bulbils and individual cloves can be propagated vegetatively, bulbils take longer up to two seasons to produce mature bulbs, and require special care because the young plants are very small and fragile (Anonymous, 2001).

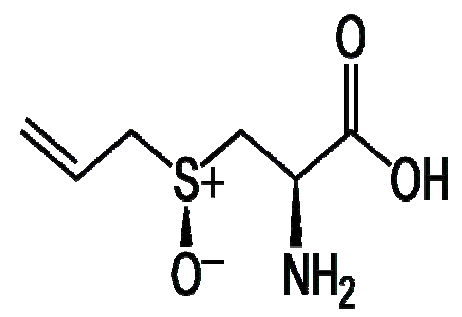

Figure 1. Chemical structure of Alliin.

\section{Medicinal importance}

Garlic (Allium sativum) is an important culinary and medicinal plant used worldwide. Garlic, like many other members of Alliums, contains high organic sulphur compounds in the form of alkylcysteine sulphoxides and $\gamma$-glutamyl peptides. On tissue damage and with alliinase enzyme's activity, the alkyl cysteine sulphoxide releases compounds that give unique Allium's odour and flavour. It shows several biological activities such as antibiotic, antitumour, antiatherosclerotic (Chanprame et al., 1998; Campbell et al., 2001; Nasim et al., 2009a,b; Nasim et al., 2010), cholesterollowering effect (Yeh and Liu, 2001) and also prevent cardiovascular disorders (Rahman, 2001).

\section{Micropropagation and in vitro Alliin production}

Cultivated garlic is sexually sterile crop and exclusively propagated vegetatively (Novak, 1990). Conventionally the use of seed bulb is the only way for cultivation of garlic. For each plant one seed bulb is needed. The lack of the availability of seed bulbs is the limitation for its large scale propagation. In addition, Garlic is one of the major spice crops of Bangladesh. It is being cultivated on an area of 13077 hectare with a total production of 42805 tons, the average yield is $3.74 \mathrm{t} / \mathrm{ha}$ (BBS 1998). The yield of garlic in Bangladesh is very low in compare to other garlic growing countries, like China (7.9 t/ha), Thailand (7.8 t/ha) and Korea (5.0 t/ha). The local cultivars of Bangladesh are infected by viruses causing low yield (Anonymous, 2001). As garlic is propagated vegetatively; viruses are transmitted to the next generation. Propagation of garlic is mainly accomplished by vegetative methods, which demonstrate a low coefficient of multiplication (Novak, 1990; Nagakubo et al., 1993); therefore it takes many years to produce sufficient number of seed bulbs for practical cultivation of new elite variety (Nagakubo et al., 1993). Similarly, the crop improvement by cross fertilization is limited as garlic shows sexual incompatibility (Masanori et al., 1995).

There are reports of using in vitro methods for propagation of garlic (Novak, 1990; Nagakubo et al., 1993; Seabrook, 1994; Zel et al., 1997, Nasim et al., 2009a,b). However, a few work reported using meristem for its micropropagation (Moriconi et al., 1990). In Allium, callus culture and in vitro morphogenesis have been achieved from various plant parts (Barandiaran et al., 1998; Myers and Simon, 1998; Robledo-Paz, et al., 2000; Sata, et al., 2001) but the rate of multiplication and the number of plantlets regenerated per explants were not always significantly high. The formation of multiple bulblets from single explant is the most desirable one. In vitro bulblet formation of garlic has also been reported (Moriconi et al., 1990). Multiple bulblet formation was induced by using in vitro developed plantlets, which were acclimatized in out door candition (Roksana et al., 2002).

Khar et al. (2005) studied on the effect of different plasmids and suitability of explants towards Agrobacterium transformation using three genotypes of 
Allium. There were no significant differences among genotypes, however; the two plasmids showed significant variables response in transient Gus assays. Plant regeneration through somatic embryogenesis is rare but is not uncommon in Allium (Sata et al., 2001). It has several advantages over organogenesis and appears to be the most promising technique for fast propagation of plants (Ignacimuthu, 1995). The developmental protocols to establish embryonic cultures with synchronous embryo forming ability may able to eliminate many of the problems associated with zygotic embryo development.

A simple high frequency direct somatic embryogenesis system is reported from basal part of clove in Allium sativum cv. Yamuna Safed in which we investigated (Nasim et al., 2009a,b) the role of auxins and cytokinins in somatic embryogenesis.Attention has also been paid to identify the biochemical differences that existed between callus and embryogenic tissues in Allium sativum during plant regeneration. In addition Nasim et al. (2010) also reported the effect of sulphur supplementation on Alliin production in different plant organs viz; leaf, root, plantlet, non-embryogenic and embryogenic callus, proliferated, matured and germinated embryos grown under invitro conditions. Evaluation of alliin content of in-vitro grown tissues both in normal (control) and sulphur supplemented conditions showed that sulphur treatment at supply of $16 \mathrm{mg} \mathrm{l}^{-1}$ gypsum $\left(\mathrm{CaSO}_{4}\right)$ significantly enhanced the production of alliin content in all in-vitro grown tissues and organs. The maximum alliin content was recorded in leaves (Nasim et al., 2010).

\section{Artemisinin \\ Sources}

The genus Artemisia belongs to the family Compositae. The leaves of the many species of Artemisia having the madicinal properties (Abdin et al., 2003); being used in the treatment of maleria due to which more than 275 million people worldwide effecting and is the cause of at least 1 million deaths every year (Butler, 1997).

\section{Medicinal importance}

As one of the world's most serious parasitic diseases, malaria, caused by Plasmodium, causes at least 500 million cases globally every year, resulting in more than one million deaths. The biggest challenge facing in the fighting against malaria is the multi-drug resistance of Plasmodium strains to the widely used antimalarials such as chloroquine, mefloquine and sulfadoxinepyrimethamine (Greenwood and Mutabingwa, 2002; Liu et al., 2006), is known for the drug artemisinin; an effective antimalarial drug against chloroquinine-resistant and chloroquininesensitive strains of Plasmodium falciparum and against cerebral malaria. Likewise, its effectiveness has been demonstrated in the treatment of skin diseases and it is also a natural herbicide.Artemisinin (Figure 2) is a sesquiterpenoid isolated from the Chinese herb 'qing hao' (Artemisia annua).

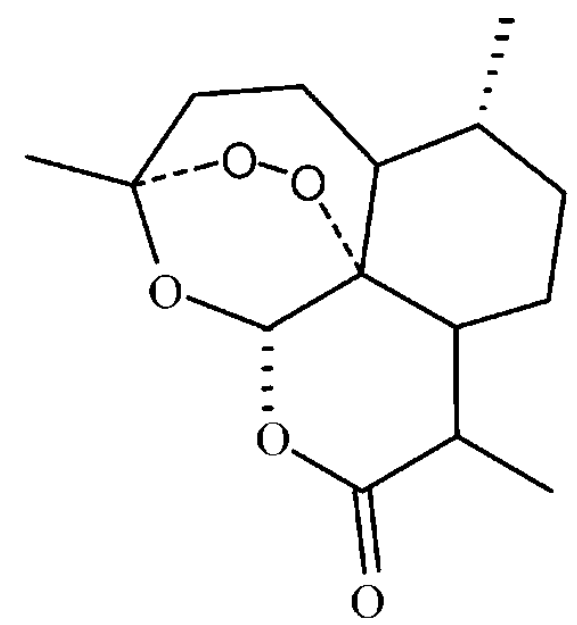

Figure 2. Chemical structure of Artimisnin.

It is effective against both chloroquinine-resistant and chloroquininesensitive strains of Plasmodium falciparum 
and similarly against the cerebral malaria. It may have some hallucinogenic properties. A. absinthium $\mathrm{L}$. is traditionally used because of its antiheliminthic, insecticidal, antiseptic and febrifuge properties Abdin et al. (2003). At present, the commercial source of the drug is the leaves and flowering tops of fieldgrown $A$. annua plants, which are subject to seasonal and somatic variations (Abdin et al. 2003).

\section{Micropropagation and in vitro Artemisinin production}

The only commercial source of the drug is extracted from fieldgrown leaves and flowering tops of Artemisia annua L., which are subject to seasonal and somatic variation (Paniego and Giulietti, 1994). Artemisinin content in $A$. annua is very low $(0.01-1 \%$ dry weight, DW), and the demand for artemisinin is increasing along with the increasing number of people suffering from malaria. Various approaches have been attempted to increase artemisinin production including chemical synthesis. Using shoot tips Nin et al. (1996) established a high regeneration protocol for A. absinthium. In addition, Zia et al. (2007) evaluate the effect of different combinations of auxins and cytokinins on callogenesis and organogenesis in $A$. absinthium.

Artemisinin production has been extensively studied in shoot and hairy root cultures. (Liu et al., 1998; Xie et al., 1995). An internal-loopmist bioreactor has been devised and applied to the shoot and hairy root cultures of $A$. annua, achieving an artemisinin yield of $46.9 \mathrm{mgl}^{-1}$ in 25 days, much higher than that in the shake-flasks (Liu et al., 1998). Hairy root cultures exposed to red light at $660 \mathrm{~nm}$ achieved a higher growth rate and artemisinin content compared to those exposed to green, blue, yellow or white light. Climatic condition together with the way and time of planting and harvesting of $A$. annua can influence artemisinin production in $A$. annua
(Wallaart et al., 1999, 2000; Abdin et al., 2003).

The genetic engineering of the pathway genes involved in artemisinin biosynthesis in A. annua (Vergauwe et al., 1996; Chen et al., 2000; Xie et al., 2001; Martin et al., 2003; Ro et al., 2006), but not much success has been recorded because of the high cost or complex nature of the gene regulation and expression in artemisinin biosynthesis. New approaches, cheaper and more convenient, are needed for improving artemisinin production.

Plant hormone such as $\mathrm{GA}_{3}, \mathrm{BA}$ and kinetin may also influence artemisinin production (Whipkey et al., 1992; Fulzele et al., 1995; Smith et al., 1997; Weathers et al., 2005). In addition, stress conditions such as light, temperature and watering may have effects on artemisinin production too (Guo et al., 2004; Wallaart et al., 2000). HPLC analysis was carried out for each level (different developmental stages) and it was found that the plant seeding to salinity stress had higher contents of artemisinin (2-3\% DW) compared to those without treatment $(1.0-1.5 \%$ DW). The result analyzed with two-side $\mathrm{T}$ test suggested that the enhancement of artemisinin content caused by $2 \mathrm{~g}^{-1} \mathrm{NaCl}$ stress was not significant compared to the control, but the enhancement caused by 4 and $6 \mathrm{~g} / 1 \mathrm{NaCl}$ stresses was extremely significant $(\mathrm{P}<0.01)$ compared to the control. Various approaches have been previously tried to enhance artemisinin production (Vergauwe et al., 1996; Chen et al., 2000; Xie et al., 2001; Liu et al., 2002) and it was found that light spectrum would influence biomass and artemisinin content of transformed hairy roots. The highest biomass $\left(5.73 \mathrm{~g} \mathrm{DW}^{-1}\right)$ and artemisinin content $\left(31 \mathrm{mg}^{-\mathrm{g}}\right)$ were obtained under red light at $660 \mathrm{~nm}$ which were 17 and $67 \%$ higher than those obtained under white light, respectively. Liu et al. (2002) found that light irradiation influenced the growth and production of artemisinin in transformed hairy root cultures of $A$. annua 
too. When hairy roots were cultured under illumination of 3,000 Lux for $16 \mathrm{~h}$ using several cool-white fluorescent lamps, the dry weight and artemisinin concentration reached 13.8 and $244.5 \mathrm{mg}^{-1}$, respectively.

Xie et al. (2001) infected A. annua leaf pieces and petiole segments with $A$. rhizogenes and obtained a clone of hairy root with artemisinin content of $0.12 \%$ DW. Vergauwe et al. (1996) transformed A. annua plants mediated by Agrobacterium tumefaciens and slightly higher artemisinin content $(0.17 \%$ DW) in the leaves of regenerated plant than normally cultured plant $(0.11 \% \mathrm{DW})$ was achieved. Chen et al. (2000) transformed a cDNA encoding cotton FDS (farnesyl diphosphate synthase) under the control of CaMV 35 S promoter into $A$. annua via $A$. tumefaciens or A. rhizogenes. By overexpressing FDS, a key enzyme in the biosynthesis of artemisinin, in transgenic plants the artemisinin content could reach 2 - 3\% DW, the highest artemisinin content in $A$. annua reported so far, by the procedure of treating plants with suitable concentrations of $\mathrm{NaCl}$.

Rita et al. (2007) established a regeneration protocol $A$. annua $\mathrm{L}$. and quantified the production of artemisinin and flavonoids in different aerial parts of in vitro raised plantlets. Artemisinin content in $A$. annua was enhanced through salinity stress Qian et al. (2007).

Sujatha et al. (2008) reported mass propagation through in vitro liquid culture technology fortified with 6-benzyl adenine (BA). The plantlets were then acclimatized under standard laboratory conditions and later under greenhouse conditions. Sharaf and Shereen (2009) reported a high regeneration protocol. Shoot cultures of Artemisia annua L. were cultivated in three different micropropagation systems: an ultrasonic nutrient mist bioreactor (UNMB), a modified ultrasonic nutrient mist bioreactor (MUNMB) and solid culture in Magenta boxes. The shoots cultivated in the UNMB and MUNMB showed excellent growth. The dry weight increase (35 times) of shoot cultures in the MUNMB was higher than those (25 times and 19 times) in both the UNMB and the Magenta boxes. Additionally, artemisinin content of shoot cultures in the MUNMB was 1.2-2.0-fold higher than those in both the UNMB and the Magenta boxes, respectively. The modified ultrasonic nutrient mist bioreactor was found to be advantageous for A. annua L. shoot cultures and artemisinin production (Sharaf and Shereen, 2009).

\section{Podophyllotoxin \\ Source}

Podophyllotoxin is the most abundant lignan isolated from Podophyllin, a resin produced by species of the genera Podophyllum (Berberidaceae).

\section{Medicinal importance}

Podophyllotoxin (Figure 3) is an antitumor aryltetralin lignan, commonly used in the treatment of numbers of cancers (Issell et al., 1984).

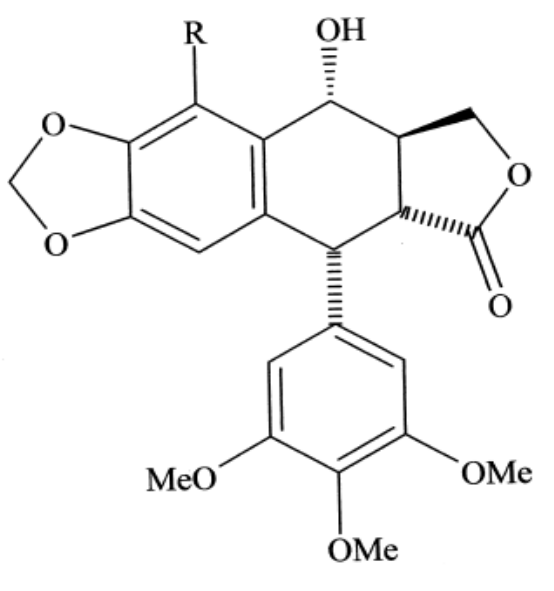

R=H : Podophyllotoxin
R=OMe: 5-Methoxypodophyllotoxin

\section{Figure 3. Chemical structure of Podophyllotoxin.}

\section{Micropropagation and in vitro Podophyllotoxin production}

The genus Podophyllum is an important anticancerous plant, growing sexually, but due to the seed dormancy 
growth rate is very noticeable, which limits the podophyllotoxin production. The alternative way to overcome the problem is in vitro cell and tissue culture. Using, in vitro technique, the first time podophyllotoxin was quantified by the Kadkade (1981, 1982). A number of researchers used various explants, different types of elicitors and precursor to enhance the level of podophyllotoxin (Hyenga et al., 1990; Kim et al., 2007). A podophyllotoxin precursor (Coniferyl alcohol, and b-cyclodextrin) was added in the $P$. hexandrum suspension culture and a remarkable variation was noticed in yield, when compared with the non added precursor in the medium (Woerdenberg et al., 1990). Kim et al. (2007) reported the establishment of plantlet regeneration of $P$. peltatum via somatic embryogenesis. Somatic embryos differentiated directly from cotyledon explants of zygotic embryos. The germinated embryos grow into plantlets with well developed roots. Rooted plantlets were acclimatized. Anbazhagan et al. (2008) induced somatic embryogenesis and quantified podophyllotoxin in $P$. peltatum and used elicitor which strongly enhanced the production of podophyllotoxin in vitro raised culture.

\section{Taxol}

\section{Source}

The genus Taxus belongs to the family Taxaceae having the seven species. These species are slow growing evergreen trees that occur in various geographical areas and accumulate taxol to a higher or lower extent. Taxol (plaxitaxol) (Figure 4), a complex diterpene alkaloid originally, the main source of taxol is bark, but it is also extracted from different parts.

\section{Medicinal importance}

In 1983, Food and drug administration had approved taxol for the treatment of ovarian and breast cancer, lung cancer, malignant melanoma, as well as AIDS etc. (Wickremesinhe and Arteca, 1993; 1994, Cragg et al., 1993), because it played a potent role on microtubular cell system (Jordan and Wilson, 1995).

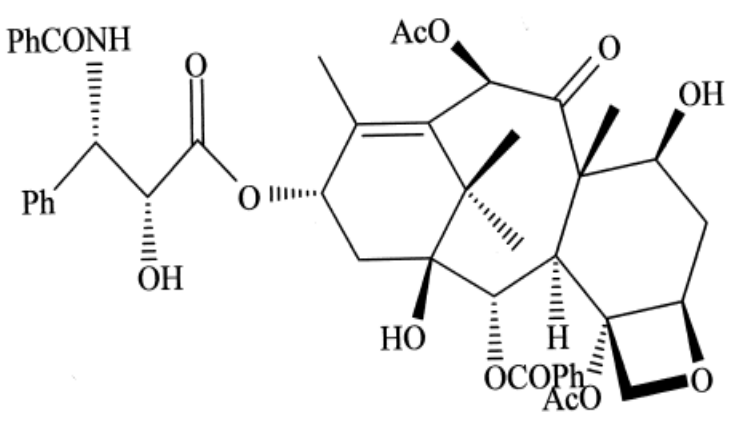

Taxol

Figure 4. Chemical structure of Taxol.

\section{Micropropagation and in vitro Taxol production}

The main source of the taxol being yew trees. Wani and his colleagues for the first time discovered a novel anticancer diterpene amide,"taxol" from the Pacific yew (Taxus brevifolia) extract (Wani et al., 1971). The high demand for the drug cannot be met by extraction from the trees due to the scarcity and slow growth of Taxus yew trees and the low Taxol content (Zhong and Zhu, 1995). Chemically, taxol is a very complex in structure; therefore, the synthesis at industrial level is not economic friendly. To over come the scarcity of the Taxus tree, and to reduced the synthetic cost, in vitro micropropagation being a good technology to produced the plantlets in masses and its production in several ways viz; forestry, and taxol production. In vitro micropropagation of Taxus spp. is recommended as one of the approach available to produced taxus plantlets, continious supply of taxol and other related $\mathrm{t}$ derivatives (Slichenmyer and Von Horf, 1991).

The first time, in vitro taxol production was carried out by the Christen et al. (1989), thereafter, similar approached 
has been adopted in severeral research laboratories throughtout the world (Flores and Sgrignoli, 1991; Ma et al., 1994; Lee et al., 1995; Yukimune et al., 1996; Jha et al. 1998; Nguyen et al., 2001; Wu et al., 2001; Linden et al., 2001; Parc et al., 2002; Abbasin et al., 2010).

The seeds of the taxus species undergoes for a lengthy dormancy period which can be overcome using in vitro method. Viable embryos were excised from seeds of Taxus brevifolia and four cultivars and were cultured on Whites', Gamborg's B5 and Murashige and Skoog's medium under dark or light conditions. Embryos excised from green seeds with undeveloped arils showed the highest germination rates, as the seeds approached maturity, in vitro germination rates of the excised embryos declined dramatically (Flores and Sgrignoli, 1991).

Various types of medium supplements have been studied aiming to enhance the taxol production. Fett- Neto et al. (1994) used different amino acids and phenylalanine to the culture medium of $T$. cuspidata and reported a significant increased in taxol production. Lee et al., (1995) reported remarkable differences in taxol content in bark and leaf tissues of in vitro developed taxus culture (Lee et al., 1995).

Biomass accumulation and the taxol production has been studied by Srinivasan et al. (1995) in cell suspension culture of $T$. baccata. In addition, an aquivalent amount (Kim et al., 1995) of paclitaxel was also reported from T. brevifolia cell suspension cultures. Effect of media compositions and other factors were evaluated on the production (Fett-Neto et al. 1995) of paclitaxel production in $T$. cuspidata. Morever, addition of different carban sources increased the paclitaxel production (Ketchum and Gibson, 1996; Ketchum et al., 2003). Use of the biotic and abiotic elicitors to improve taxol production has been studied (Strobel et al., 1992; Ciddi et al., 1995; Yukimune et al., 1996; Jha et al. 1998). Ellis et al., (1996) established cultures using nodal segment in seven Taxus cultivars and screened the taxol production. Similarly, various Taxus species has been widely explored as an alternative for the production of Taxol and other useful taxane compounds in the world (Abdin et al., 2003).

Majeda et al. (2000) reported a high yielding procedure for the in vitro propagation of juvenile material of $T$. baccata with respect to the taxane contents. A positive correlation was found between growth and secondary metabolites yield. Tsay (2001) reported a high regeneration protocol for Taxus mariei using bud explants derived from approximately 1,000-year-old field-grown trees, and a comparison was made with bud explants derived from 1-year-old stecklings raised from rooted cuttings of these trees. The steckling-derived cultures performed better than mature tree-derived cultures in terms of shoot multiplication and rooting ability. Taxus genotypes were cultured and screened for the taxol production by Parc et al. (2002). Bud explants and the embryos were used as experimental material, and placed on the different auxins type and cytokines. And it was noticed that micro propagation was auxins, cytokinin concentrations and genotype dependent. Plantlets were successfully acclimatized and established in outdoor conditions (Abbasin et al., 2010).

\section{Conclusion}

Since long human being used and still continiously using plants in the form of carbohydrates, fat, food, protein, and shelter etc. Morever, its also a sources of variety of secondary metabolites, which being used in the production of several valuable products (agrochemicals, biopestisides, colours, flavours, fragrances, food additives and pharmaceuticals). The commercial values of plant secondary metabolites have been the main impetus for the enormous research effort put into understanding and manipulating their 
biosynthesis using various chemical, physiological and biotechnological pathways. The information scored in the present communication would be highly valuable to understand the role of biotechnological intervention to enhance the level to meet the required demand of selected secondary metabolites.

\section{Acknowledgement}

Dr. Junaid Aslam greatfully acknowledge the Chairman (Al Haj Saeed Bin Ahmed Al Lootah), Board of Trustees of Dubai Pharmacy College for providing all the research facilities and Prof. Karamat A. Javaid, Dr. Heyam Saad, Dr. Amina Mahdy Sallam, Dr. Naglaa Gamil, Dr. Bazigha AlTemimy, Dr. Fazilatun Nessa, and Mrs. Sabeena Salam for their kind cooperation.

\section{References}

Abdin, M. Z., M. Israr, R. U., Rehman, S. K. and S. K. Jain. 2003. Artemisinin a novel antimalarial drug: biochemical and molecular approaches for enhanced production. Planta Med. 69:289-299.

Abbasin, Z., S. Zamani, S. Movahedi, G. Khaksar and B. E. S. Tabatabaei. 2010. In vitro micropropagation of Yew (Taxus baccata) and Production of Plantlets. Biotechnol. 9:48-54.

Akerele, O. 1992. WHO Guidelines for the Assessment of Herbal Medicines. Fitotherapia 2:99-110.

Anonymous. 2001. National Horticultural Research and development Foundation, Nasik, Maharashtra. NHRDF Newsletter.

Anbazhagan, V. R., C. H. Ahn, E. Harada, Y. S. Kim and Y. E. Choi. 2008. Podophyllotoxin production via cell and adventitious root cultures of Podophyllum peltatum. In Vitro Cell. Develop. Biol-Plant. 44(6):494-501.

Barandiaran, X., A. Die Pietro and J. Martin. 1998. Biolistic transfer and expression of a uidA reporter gene in different tissues of Allium sativum L. Plant Cell Rep. 17:737-741.

Butler, D. 1997. Time to put malarial control on the global agenda. Nature 386:535-541.

Campbell, J. H., J. L. Efendy, N. J. Smith and G. R. Campbell. 2001. Molecular basis by which garlic suppresses atherosclerosis. J. Nutr. 131:10061009.

Chanprame, S., T. M. Kuo and J. M. Widholm. 1998. Soluble carbohydrate content of soybean (Glycine max L.) Merr. Somatic and zygotic embryos during development. In Vitro Cell. Develop. Biol. Plant 34:64-68.

Chen, D. H., H. C. Ye. and G. F. Li. 2000. Expression of a chimeric farnesyl diphosphate synthase gene in Artemisia annua L. transgenic plants via Agrobacterium tumefaciensmediated transformation. Plant Sci. 155:179-185.

Christen, A. A., J. Bland, and G. M. Gibson. 1989. Cell cultures as a means to produce taxol. Proc. Amer. Assoc. Canc. Res. 30:566.

Ciddi, V., V. Srinivasan and V. M. L. Shuler. 1995. Elicitation of Taxus cell cultures for production of taxol, Biotechnol. Let. 17:1343-1346.

Cragg, G. M., S. A. Schepartz, M. Suffuess and M. R. Grever. 1993. The taxol supply crisis. New NCI policies for handling the large-scale production 
of novel natural product anticancer and anti-HIV agents. J. Nat. Prod. 56:1657-1668.

Doran, P. M. 2000. Foreign protein production in plant tissue cultures. Cur. Opi. Biotech. 11:199-204.

Ellis, D. D., E. L. Zeldin, M. Brodhagen, W. A. Russin and B. H. McCown. 1996. Taxol production in nodule cultures of Taxus. J. Nat. Prod. 59:246-250.

Fett-Neto, A. G., J. J. Pennington and F. DiCosmo. 1995. Effect of white light on taxol and baccatin III. Accumulation in cell cultures of Taxus cuspidata Sieb and Zucc. J. Plant Physiol. 146:584-590.

Fett-Neto, A. G., J. M. Stewart, S. A. Nicholson, J. J. Pennington and F. DiCosmo. 1994. Improved taxol yield by aromatic carboxylic acid and amino acid feeding to cell cultures of T. cuspidata. Biotechnol Bioeng. 44:967-971.

Flores, H.E. and P.J. Sgrignoli. 1991. In vitro culture and Precocious germination of Taxus embryos. In Vitro Cell. Dev. Biol. Plant. 27:139142.

Fulzele, D. P., M. R. Heble. and P. S. Rao. 1995. Production of terpenoid from Artemisia annua L. plantlet cultures in bioreactor. J. Biotechnol. 40:139143.

Greenwood, B. and T. Mutabingwa. 2002. Malaria in 2002. Nature 415:670672.

Guo, C., C. Z. Liu, H. C. Ye and G. F. Li. 2004. Effect of temperature on growth and artemisinin biosynthesis in hairy root cultures of Artemisia annua. Acta Bot. Boreal-Occident Sin. 24:1828-1831.
Hyenga, A. G., J. A. Lucas and P. M. Dewick. 1990. Production of tumourinhibitory lignans in callus cultures of Podophyllum hexandrum. Plant Cell Rep. 9:382-385.

Ignacimuthu, S. 1995 Plant cell and tissue culture. In: S. Ignacimuthu, (Ed.). pp.100-142. Basic Biotechnology, TATA McGraw-Hill Pub. Co Ltd., New Delhi, India.

Junaid, A., S. A. Nasim, A. Mujib, and M. P. Sharma 2009. Screening of vincristine yield in ex vitro and in vitro somatic embryos derived plantlets of Catharanthus roseus L. (G.) Don. Sci. Hort. 119:325-329.

Junaid, A., Fatima, Z., A. Mujib, and M. P. Sharma 2010. Variations in vinblastine production at different stages of somatic embryogenesis, embryo and field grown plantlets of Catharanthus roseus L. (G) Don, as revealed by HPLC. In Vitro Cell. Dev. Bio. Plant (in press).

Jha, S. D., Sanyal, B., Ghosh, T. and B. Jha. 1998. Improved taxol yield in cell suspension culture of Taxus wallichiana (Himalayan yew). Planta Med. 64:270-272.

Jordon, M. A. and L. Wilson. 1995. Microtuble polymerization dynamics, mitotic, and cell death by paclitaxel at low concentration, American Chemical Society Symposium Series, Vol. 583, Chapter X, pp. 138-153.

Kadkade, P. G. 1981. Formation of podophyllotoxin by Podophyllum peltatum tissue cultures. Naturwiss 68:481-482.

Kadkade, P. G. 1982. Growth and podophyllotoxin production in callus tissues of Podophyllum peltatum. Plant Sci. Let. 25:107-115. 
Ketchum, R., C. D. Rithner, D. Qiu, Y. S. Kim, R. M. Williams and R. B. Croteau. 2003. Taxus metabolites: methyl jasmonates preferentially induces production of taxoids oxygenated at $\mathrm{C}-13$ in Taxus media cell cultures. Phytochemistry 62(6):901-909.

Ketchum, R. E. B. and D. M. Gibson. 1996. Paclitaxel production in suspension cell cultures of Taxus. Plant Cell Tissue Org. Cult. 46:9-16.

Khar, A., R. C. Yadav, N. Yadav and R. D. Bhutani. 2005. Transient gus expression studies in onion (Allium Cepa L.) and garlic (Allium sativum) Akdeniz Üniversitesi Ziraat Fakultesi Dergisi 18(3):301-304.

Kim, J. H., J. H. Yun, Y. S. Hwang, S. Y. Byun and D. I. Kim. 1995. Production of taxol and related taxanes in Taxus brevifolia cell cultures: Effect of sugar. Biotechnol. Lett. 17(1):101-106.

Kim, Y. S., S. Lim, Y. E. Choi and V. Ramesh Anbazhagan. 2007. High frequency plant regeneration via somatic embryogenesis in Podophyllum peltatum L., an important source of anticancer drug. Curr. Sci. 92 (5):662-664.

Lee, C. Y., F. L. Lin, C. T. Yang, L. H. Wang, H. L. Wei and H. S. Tsay. 1995. Taxol production by cell cultures of Taxus mairei. Proceeding of Symposium on development and utilization of resources of medicinal plants in Taiwan, Taiwan Agricultural Research Institute, Taiwan, April 21, TARI Special Publication 48:137-148.

Linden, J. C., J. R. Haigh, N. Mirjalili. and M. Phisaphalong. 2001. Gas concentration effects on secondary metabolite production by plant cell cultures. Adv. Biochem. Eng. Biotechnol. 72:27-62.

Liu, C. Z., C. Guo, Y. C. Wang and F. Ouyang. 2002. Effect of light irradiation on hairy root growth and artemisinin biosynthesis of Artemisia annua L. Process Biochem. 38:581585 .

Liu, E. T., V. A. Kuznetsov and L. D. Miller. 2006. In the pursuit of complexity: systems medicine in cancer biology. Cancer Cell 9:245247.

Liu, C. Z., Y. C. Wang, C. Guo, F. Ouyang, H. C. Ye and G. F. Li. 1998. Production of artemisinin by shoot cultures of Artemisia annua L. in a modified inner-loop mist bioreactor. Plant Sci. 135:211-217.

Ma, W., G. L. Park, G. A. Gomez, M. H. Nieder, T. L. Adams, J. S. Aynsley, O. P. Sahai, R. J. Smith, R. W. Stahlhut and P. J. Hylands. 1994. New bioactive taxoids from cell cultures of Taxus baccata. J. Nat. Prod. 57:116-122.

Majeda, J. P. 2000. One step more towards taxane production through enhanced Taxus propagation. Plant Cell Rep. 19:825-830.

Martin, V. J. J., D. J. Pitera, S. T. Withers, J. D. Newman and J. D. Keasling. 2003. Engineering a mevalonate pathway in Escherichia coli for production of terpenoids. Nat. Biotechnol. 21:796-802.

Masanori, A., T. Kenji and S. Shinichiro. 1995. Regeneration of whole plant from tissue-cultured shoot primodia of garlic (Allium sativum L.). Plant Cell Rep. 15:17-21. 
Moriconi, D. N., V. C. Conci and S. F. Nome. 1990. Rapid multiplication of garlic (Allum sativum L.) in vitro. Physiol. Planta. 15:473 - 497.

Mujib, A. and J. Samaj, 2006. Somatic embryogenesis. Springer-Verlag, Berlin, Heidelberg, New York

Murch, S. J., S. K. Raj and P. K. Saxena. 2000. Phytopharmaceuticals: mass production, standard, and conservation. Sci. Rev. Alte. Med. 4:39-43.

Myers, J. M. and P. W. Simon. 1998. Continuous callus production and regeneration of garlic (Allium sativum L.) using root segments from shoot tip-derived plants. Plant Cell Rep. 17:726-730.

Nagakubo, T., A. Nagasawa and H. Ohkawa. 1993. Micropropagation of garlic through in vitro bulblet formation. Plant Cell Tissue Org. Cult. 32:175-183.

Nasim, S. A., A., Mujib, K., Rashmi, F. Samar, A., Junaid and Mahmooduzzafar. 2009a. Improved Allin Yield in somatic embryos of Allium Sativum L. (C.V. Yamuna Safed) as analyzed by HPTLC. Acta Biol. Hung. 60(4):441-454.

Nasim, S. A., B. Dhir, F. Samara, K. Rashmi, A. Mujib and Mahmooduzzafar. 2009b. Sulphur treatment alters the therapeutic potency of alliin obtained from garlic leaf extract. Food Chem. Toxico. 47:888-892.

Nasim, S. A., B. Dhir, R. Kapoor, S. Fatima, Mahmooduzzafar and A. Mujib. 2010. Alliin production in various tissues and organs of Allium sativum grown under normal and sulpur -supplemented in vitro conditions. Plant Cell Tiss. Org. cult. DOI 10.1007/s11240-009-9664-1

Nguyen, T., J. Eshraghi, G. Gonyea, R. Ream and R. Smith. 2001. Studies on factors influencing stability and recovery of paclitaxel from suspension media and cultures of Taxus cuspidata cv Densiformis by high performance liquid chromatography. J. Chromat. A. 911:55-61.

Nin, S., E. Morosi, S. Schiff and A. Bennici. 1996. Callus culture of Atremisia absinthium L. initiation, growth optimization and organogenesis. Plant Cell Tissue Org. Cult. 45:67-72.

Novak, F. J. 1990. Allium tissue culture. In: H. D. Rabinowitch and J. L. Brewster (Eds.). pp. 767-768. Onion and Allied Crops, CRC Boca Raton, Florida.

Paniego, N. B. and A. M. Giulietti. 1994. Artemisia annua L.: dedifferentiated and differentiated cultures. Plant Cell Tissue Org. Cult. 36:163-168.

Parc, G., A. Canaguier, P. Landre, R. Hocquemiller, D. Chriqui and $\mathrm{M}$. Meyer. 2002. Production of taxoids with biological activity by plants and callus cultures from selected Taxus genotypes. Phytochemistry 59:725730 .

Qian, Z., K. Gong, L. Zhang, J. Lv, F. Jing, Y Wang, S. Guan, G. Wang and K. Tang 2007. A simple and efficient procedure to enhance artemisinin content in Artemisia annua L. by seeding to salinity stress. Afr. J. Biotechnol. 6(12):1410-1413.

Roksana, R. M., F. Alam, R. Islam and M. M. Hossain. 2002. In vitro Bulblet Formation from Shoot Apex in Garlic 
(Allium sativum L.). Plant Tissue Cult. 12(1):11-17.

Rahman, K. 2001. Historical perspective on garlic and cardiovascular disease. J. Nut. 131:977-979.

Ramachandra, R. S. and G. A. Ravishankar. 2002. Plant cell cultures: Chemical factories of secondary metabolites. Biotechnol. Advan. 20:101-153.

Ravishankar, G. A. and L. V. Venkataraman. 1993. Role of plant cell cultures in food biotechnology: commercial prospectus and problems. New Delhi: Oxford IBH Press: 255-274.

Rita, B., I. Benedetta P. Stefano M. Giancarlo F. V. Franco and R.B. Anna. 2007. Distribution of artemisinin and bioactive flavonoids from Artemisia annua L. during plant growth. Biochem. System. Ecol. 36(5-6):340-348.

Ro, D. K., E. M. Paradise, M. Ouellet, K. J. Fisher, K. L. Newman, J. M. Ndungu, K. A. Ho, R. A. Eachus, T. S. Ham, J. Kirby, M. C. Chang, S. T. Withers, Y. Shiba, R. Sarpong and J. D. Keasling. 2006. Production of the antimalarial drug precursor artemisinic acid in engineered yeast. Nature 440:940- 943.

Robledo-Paz, A., V. M. VillalobosArambula and A. E. Jofre-Garfias. 2000. Efficient plant regeneration of garlic (Allium sativum L.) by root tip culture. In Vitro Cell. Dev. Biol. Plant 36:416-419.

Sajc, L., D., Grubisic, G. and VunjakNovakovic. 2000. Bioreactors for plant engineering: an outlook for further research. Biochem. Eng. J. 4:89-99.
Sata, S. J., B. Bagatharia and V. S. Thaker. 2001. Induction of direct embryogenesis in garlic (Allium sativum L.). Meth. Cell Sci. 22:299304.

Seabrook, J. E. E. 1994. In vitro propagation and bulb formation of garlic. Canadian J. Plant Sci. 74:155158.

Sharaf, E. M. and E. Shereen. 2009. Artemisinin Production from Different Shoot Culture Systems of Artemisia annua L. Aust. J. Basi. Appl. Sci. 3(3):2212-2216.

Slichenmyer, W. J. and D. D. Von Horf. 1991. Taxol: A new and effective anticancer drug. Anti-Cancer Drugs 2:519-530.

Smith, T. C., P. J. Weathers and R. D. Cheetham. 1997. Effects of gibberellic acid on hairy root cultures of Artemisia annua: growth and artemisinin production. In Vitro Cell. Dev. Biol. Plant 33:75-79.

Srinivasan, V., L. Pestchanker, S. Moser, T. Hirasuma, R. A.Taticek and M. L. Shuler. 1995. Taxol production in bioreactors; kinetics of biomass accumulation, nutrient uptake, and taxol production by cell suspensions of Taxus baccata. Biotechnol. Bioeng. 47:666-676.

Strobel, G. A., A. Stierle and J. G. M. Van Kuijk. 1992. Factors influencing the in vitro production of radiolabelled taxol by Pacific yew, Taxus brevifolia. Plant Sci. 84:65-74.

Sujatha G., D. R. K. Bollipo, L. C. Pier and F. Guido. 2008. Mass propagation and essential oil analysis of Artemisia vulgaris. J. Biosci. Bioeng. 105(3):176-183. 
Tsay, H. S. 1999. Tissue culture technology of medicinal herbs and its application of medicinal herbs and its application in Taiwan. In: C. H. Chou, G. R. Waller and C. Reinhardt (Eds.). pp. 137-144. Biodiversity and Allelopathy: from Organisms to Ecosystems in The Pacific. Academia Sinica, Taipei, Taiwan.

Vergauwe, A., R. Cammaert, D. Vandenberghe, C. Genetello, M. Van Montagu and E. Van den Eeckhout 1996. Agrobacterium tumefaciens mediated transformation of Artemisia annua L. and regeneration of transgenic plant. Plant Cell Rep. 15:929-937.

Wallaart, T. E., N. Pras, A. C. Beekman and W. J. Quax. 2000. Seasonal variation of artemisinin and its biosynthetic precursors in plants of Artemisia annua of different geographical origin: proof for the existence of chemotypes. Planta Med. 66:57-62.

Wallaart, T. E., N. Pras and W. J. Quax. 1999. Isolation and identification of dihydroartemisinic acid hydroperoxide from Artemisia annua: a novel biosynthesis precursor of artemisinin. J. Nat. Prod. 62:1160-1162.

Wani, M. C., H. L. Taylor, M. E. Wall, P. Coggon and A. T. McPhail. 1971. Plant antitumor agents VI. The isolation and structure of taxol, a novel antileukemic and antitumor agent from Taxus brevifolia. J. Amer. Chem. Soc. 93:2325-2327.

Weathers, P. J., G. Bunk and M. C. Mccoy. 2005. The effect of phytohormones on growth and artemisinin production in Artemisia annua hairy roots. In Vitro Cell Dev. Biol. Plant. 41:47-53.
Whipkey, A., J. E. Simon, D. J. Charles and J. Janick. 1992. In vitro production of artemisinin from Artemisia annua L. Phytother. Res. $1: 15-25$.

Wickremesinhe, E. R. M. and R. N. Arteca. 1993. Taxus callus cultures: Initiation, growth optimization, characterization and taxol production. Plant Cell Tiss. Org. Cult. 35:181-193.

Wickremesinhe, E. R. M. and R. N. Arteca. 1994. Taxus cell suspension cultures: optimizing growth and production of taxol. J. Plant Physiol. 144:183-188.

Woerdenbag, H. J., W. Van Uden, H. W. Frijlink, C. F. Lerk, N. Pras and T. M. Malingre. 1990. Increased podophyllotoxin production in Podophyllum hexandrum cell suspension cultures after feeding coniferyl alcohol as a $\alpha$-cyclodextrin complex. Plant Cell Rep. 9:97-100.

Wu, J., C. Wang and X. Mei. 2001. Stimulation of taxol production and excretion in Taxus spp cell cultures by rare earth chemical lanthanum. J. Biotechnol. 85:67-73.

Xie, D. Y., Z. R. Zou, H. C. G. F. Ye, and L. Guo. 2001. Selection of hairy root clones of Artemisia annua L. for artemisinin production. Isr. J. Plant Sci. 49:129-134.

Yeh, Y. Y. and L. Liu. 2001. Cholesterollowering effect on garlic extracts and organosulfur compounds: human and animal studies. J. Nutr. 131:989993.

Yukimune, Y., H. Tabata, Y. Higashi and Y. Hara. 1996. Methyljasmonateinduced overproduction of paclitaxel and baccatin III in Taxus cell 
suspension cultures. Nat. Biotechnol. 14:1129-1132.

Zel, J., N. Debelijak, R., Ueman and M. Ravinkar. 1997. The effect of jasmonic acid, sucrose and darkness on garlic (Allium sativum L. cv. Ptujski, jesenski) bulb formation in vitro. In vitro Cell. Dev. Biol. Plant $33: 231-235$.

Zhong, J. J. and Q. X. Zhu. 1995. Effect of initial phosphate concentration on cell growth and ginsenoside saponin production by suspended cultures of Panax notoginseng. App. Biochem. Biotechnol. 55:241-246.
Zia, M., and F. C. Riaz-ur-Rehman Muhammad. 2007. Hormonal regulation for callogenesis and organgenesis of Artemisia absinthium L. Afr. J. Biotechnol. 6(16):18741878. 